Variations tibétaines, Et autres...

\title{
Alice Travers, La noblesse tibétaine du Ganden Phodrang (1895-1959) : permanences et transitions
}

\section{(2) OpenEdition}

12 Journals

Édition électronique

URL : https://journals.openedition.org/emscat/1945

DOI : $10.4000 /$ emscat. 1945

ISSN : 2101-0013

Éditeur

Centre d'Etudes Mongoles \& Sibériennes / École Pratique des Hautes Études

Référence électronique

"Alice Travers, La noblesse tibétaine du Ganden Phodrang (1895-1959) : permanences et transitions », Études mongoles et sibériennes, centrasiatiques et tibétaines [En ligne], 42 | 2011, mis en ligne le 20 décembre 2011, consulté le 13 juillet 2021. URL : http://journals.openedition.org/emscat/ 1945 ; DOI : https://doi.org/10.4000/emscat.1945

Ce document a été généré automatiquement le 13 juillet 2021.

(c) Tous droits réservés 


\section{Alice Travers, La noblesse tibétaine du Ganden Phodrang (1895-1959) : permanences et transitions}

\section{RÉFÉRENCE}

Membres du jury : Anne Chayet (rapporteur), Robert Descimon (rapporteur), Jean Duma (codirecteur de thèse), Fabienne Jagou, Jacques Legrand (Président du jury), Heather Stoddard (co-directeur de thèse). Thèse de doctorat soutenue le 7 novembre 2009 à l'Université de Paris Ouest Nanterre La Défense.

\section{La noblesse tibétaine du Ganden Phodrang (1895-1959) : permanences et transitions}

Cette thèse d'histoire sociale propose une étude prosopographique de la noblesse (tib. sku drag) liée au gouvernement central du Tibet appelé Ganden Phodrang (tib. Dga' ldan pho brang), pendant la première moitié $\mathrm{du} \mathrm{xx}^{\mathrm{e}}$ siècle. La noblesse tibétaine était une élite administrative héréditaire : ses membres se transmettaient des domaines dont la possession était liée à l'obligation, pour au moins un membre de la famille par génération, de servir le gouvernement. Ce groupe social a été étudié pour cette période par plusieurs historiens et anthropologues (Luciano Petech, Melvyn Goldstein, le Prince Pierre de Grèce et Tsering Yangdzom ${ }^{1}$ ). Ces travaux n'étudient dans le détail qu'un nombre restreint de familles de la haute aristocratie et non pas l'ensemble de la noblesse; de plus, ils s'intéressent soit aux relations matrimoniales et aux logiques lignagères, soit aux fonctionnaires du gouvernement et à la vie politique, sans étudier comme un tout, à de brèves allusions près, les sphères familiales et professionnelles. Il importait donc de porter le regard sur l'ensemble du groupe noble, et non uniquement sur les grandes familles ou les fonctionnaires, et de prendre en compte non seulement les discours normatifs sur les institutions politiques, mais aussi la façon dont les nobles 
vivaient et faisaient vivre ces institutions. Cette recherche analyse donc sans les dissocier les deux piliers de l'identité noble, l'appartenance à un lignage et le service du gouvernement, en accordant une attention particulière aux espaces où les sphères familiales et professionnelles se recoupent et interfèrent.

2 Pour reconstituer les carrières des fonctionnaires nobles et les généalogies des familles, qui formaient mon corpus de base, trois types de sources ont été mobilisés, outre la littérature secondaire : des biographies et autobiographies de nobles tibétains, publiées au Tibet, en République Populaire de Chine, et en exil, en tibétain et en anglais depuis les années $1980 ; 70$ entretiens réalisés avec des nobles tibétains nés dans la première moitié du $\mathrm{xx}^{\mathrm{e}}$ siècle et se trouvant au Tibet ou en exil, en Inde, en Europe et aux ÉtatsUnis; enfin, les archives britanniques, dépouillées en Inde et en Grande-Bretagne, qui présentaient un avantage majeur, celui de fournir des données contemporaines à l'époque étudiée alors que les sources tibétaines utilisées, que ce soient les entretiens avec des nobles tibétains ou leurs biographies ou autobiographies étaient des sources construites a posteriori.

3 La méthode prosopographique est apparue comme la plus adaptée dans la poursuite de ces objectifs. Il s'agit de constituer des notices individuelles regroupant des données biographiques de toutes sortes qui sont fournies sur des personnages ayant entre eux un lien commun, ici celui d'appartenir à la noblesse du Ganden Phodrang. Grâce à ces sources, des outils ont été constitués (liste des familles nobles, des bureaux de l'administration, des districts, et des titres et postes des fonctionnaires) ainsi qu'une base de données informatisée ou métasource sous Access, répartie en plusieurs tables qui comportent 556 individus (dont 441 fonctionnaires du Ganden Phodrang), 1210 charges exercées par ces fonctionnaires dans le gouvernement et 355 mariages.

Sur le plan théorique, cette étude est nourrie d'un certain nombre de travaux sociologiques et historiques. En histoire moderne et contemporaine de l'Europe, des études d'histoire de l'État à travers les pratiques, qui ont mis en lumière ce qu'une histoire sociale de l'administration et de l'État pouvait apporter comme éclairage nouveau sur la connaissance de l'État et des élites ${ }^{2}$, ont été jugés particulièrement fructueuses pour le Tibet. En sociologie, les travaux de Pierre Bourdieu sur les stratégies matrimoniales et le capital social et de Max Weber sur les processus de bureaucratisation et de rationalisation de l'État ${ }^{3}$ se sont avérés très éclairants pour comprendre certains mécanismes de distinction des élites tibétaines et la construction de l'État du Ganden Phodrang.

5 Pour combler les principales lacunes de la littérature concernant la noblesse tibétaine, il fallait sortir d'un questionnement centré sur sa responsabilité dans la perte de l'indépendance du Tibet. C'est la question de la perpétuation de la domination noble jusqu'en 1959 qui a semblé cruciale. La problématique qui a fourni la trame de la thèse était donc la suivante: comment la domination de cette noblesse administrative héréditaire s'est-elle trouvée confortée ou menacée par les forces d'unité et de division du groupe noble, dans une période marquée par d'intenses ruptures? Après un développement introductif qui posait le cadre méthodologique et temporel de l'étude, les problèmes liés à la définition et à l'identité du groupe noble sont présentés à travers les pratiques matrimoniales et lignagères, ce qui permet de comprendre que le groupe noble se renouvelait de façon discrète mais efficace en intégrant les classes moyennes lettrées et les nouvelles classes marchandes par le mariage. Certaines idées reçues sont réfutées, comme celle de la prévalence de la polyandrie ou de la polygynie dans la 
noblesse, en réalité très marginales, tout comme celle du principe de patrilinéarité dans la pratique - le mariage en gendre (tib. mag pa) apparaissant comme prépondérant. Une grande mobilité individuelle entre familles existait au sein du groupe, par les adoptions et les mariages, qui servait en fait une relative permanence de la structure sociale, des maisons et de la noblesse en général.

6 La deuxième partie analyse la source principale de légitimité de la domination noble, le service du gouvernement, et montre, après une description détaillée des institutions politiques et de leur évolution, que les pratiques des fonctionnaires nobles étaient tout à la fois ancrées dans le passé (caractère partiellement héréditaire des charges, non pertinence de la séparation des sphères privées et publiques) et en pleine mutation (spécialisation grandissante et croissance numérique exponentielle des bureaux et des postes dans l'administration, prépondérance plus relative de la haute aristocratie dans les plus hauts postes, mobilité sociale permise par les carrières, évolutions du système des titres honorifiques de la noblesse et des fonctionnaires suite à la chute de l'Empire mandchou en 1911).

7 Enfin, la dernière partie expose la façon dont la noblesse tibétaine a pu perpétuer sa domination par le maintien de son capital social, notamment par des stratégies de distinction innovantes sur le plan de l'éducation (en envoyant ses enfants dans des écoles en Inde par exemple), grâce à l'investissement de la sphère commerciale et à l'adoption précoce des aspects techniques des modernités étrangères avec lesquelles la noblesse était en contact.

\section{The Tibetan Aristocracy of the Ganden Phodrang (1895-1959): Continuities and Transitions}

8 This $\mathrm{PhD}$ thesis is a socio-historical investigation into the aristocracy (tib. sku drag) of the Ganden Phodrang (tib. Dga' ldan pho brang), the central government of Tibet, during the first half of the $20^{\text {th }}$ century, through a prosopographical study. The Tibetan aristocracy was a hereditary administrative elite: its members could pass on and inherit estates; however possession was linked to the obligation that at least one member of the family of each generation should serve the government.

9 This social group has been studied, for this period, by several historians and anthropologists (Luciano Petech, Melvyn Goldstein, Prince Peter of Greece, and Tsering Yangdzom). ${ }^{4}$ These works offer a detailed study of only a few families of the higherstatus aristocracy and not the entire noble group; moreover, they deal with either the subject of marriage relationships and lineages strategies, or the subject of government officials and political life, without examining the familial and professional spheres as a whole. Thus, it is important to study the noble group in its entirety, not only the higher status families and officials, and to take into consideration not only the normative discourses on the political institutions but also the way aristocrats lived and made these institutions function. Therefore, this research analyses, without dissociation, the two pillars of noble identity: belonging to a lineage and government service, with particular attention to the spaces where family and professional spheres overlap.

10 The prosopographical method was the most appropriate to achieve these aims. It involves compiling notes on individuals, and amalgamating biographical data from 
multiple sources on as many people as possible who share the common link, in this instance, forming part of the Ganden Phodrang aristocracy.

11 In order to reconstruct the noble officials' careers and the families' genealogies, which form the core material for my study, three different types of primary sources were studied: biographies and autobiographies by Tibetan nobles published since the 1980s in Tibet, in the People Republic of China, and in exile, in both Tibetan and English; 70 interviews with noblemen and noblewomen born in the first half of the $20^{\text {th }}$ century and living in Tibet or in exile, in India, Europe, or the United States; and finally, British archives in India and Great Britain, which had the major advantage of supplying data that were contemporaneous with the period under scrutiny. These were especially valuable when one considers that the Tibetan sources used, be they interviews or published biographies and autobiographies, were sources constructed a posteriori.

Thanks to these sources, tools were built up (lists of noble families, government offices, districts, officials' titles and positions), as well as a computerised database, which consisted of several "tables" comprising digitised information about 556 individuals (and among them 441 Ganden Phodrang officials), 1,210 official positions held by these officials, and 355 marriages.

On a theoretical level, this study benefited from a number of sociological and historical works. In modern European history, research on the State and its practices, which shed light on the way a social history of the administration and the State can clarify our comprehension of the State and the elites, ${ }^{5}$ was particularly fruitful with respect to Tibet. In sociology, works by Pierre Bourdieu on marriage strategies and social capital, and by Max Weber on bureaucratisation and the State, were helpful for an understanding of certain distinction mechanisms among the Tibetan aristocracy and the construction of the Ganden Phodrang State. ${ }^{6}$

14 In order to fill the gaps in the literature regarding the Tibetan aristocracy, it was necessary to avoid an approach centred on responsibility for the loss of Tibet's independence. The question of the perpetuation of the noble domination until 1959 was crucial. It was important throughout to understand how the dominance of this hereditary administrative elite was either comforted or threatened by uniting and dividing forces from within the noble group, especially during a period marked by intense changes.

15 After an introductory development that sets down the methodological and temporal frame of the study, questions of definition and identity of the Tibetan aristocracy are presented through the analysis of matrimonial and lineage strategies. This shows how the noble group renewed itself in a discreet but efficient way by integrating educated middle classes and new merchant groups through marriage. A number of stereotypes were refuted; for instance, the prevalence of polyandry and polygyny among the nobility was, in effect, shown to be marginal, as was the prevalence of the patrilineal principle in practice, since uxorilocal marriage appears to have been very common. A very significant mobility of individuals between families prevailed in the aristocracy, for instance through adoption or marriage, which provided a relative permanence to the social structure, and of the noble houses and aristocracy in general.

The second part analyses the main source for the legitimacy of noble dominance: government service. After a detailed description of the political institutions and their evolution, it shows that the officials' practices were at the same time deeply rooted in the past (government positions were still partly hereditary, and private and public 
spheres were not always clearly separated) and in the middle of major changes (the number of government offices and positions was experiencing exponential growth, the monopoly of the higher-status aristocracy on the top positions was slipping, a certain social mobility could be achieved through careers, and the officials' and nobles' honorific titles were undergoing significant changes following the fall of the Manchu Dynasty in 1911).

The final part of the thesis shows how the Tibetan nobility could perpetuate its domination by preserving its social capital, through innovating distinct strategies on the educational level, through investing in commercial activities, and by quickly adopting the technical aspects of the foreign models of modernity with which it came into contact.

\section{NOTES}

1. Petech, L. 1973 Aristocracy and Government in Tibet, 1728-1959 (Rome, Ismeo), 274 p. ; Goldstein, M.C. 1968 An Anthropological Study of the Tibetan Political System (PhD dissertation in Anthropology, University of Washington), 259 p. ; Prince Pierre de Grèce et du Danemark. 1954 The Aristocracy of central Tibet. A provisional list of names of the noble Houses of Ü-Tsang (Kalimpong, Tibet Mirror Press), 43 p.; Yangdzom, T. 2006 [version chinoise 2005] The aristocratic families in Tibetan history, 1900-1951 (Beijing, China Intercontinental Press), $272 \mathrm{p}$.

2. Descimon, R., Schaub, J.-F. et Vincent, B. (dir.). 1997 Les figures de l'administrateur. Institutions, réseaux, pouvoirs en Espagne, en France et au Portugal, 16 $6^{e}-19^{e}$ siècles (Paris, éd. de l'EHESS), 242 p.; Reinhard, W. et Descimon, R. (dir.). 1996 Les élites du pouvoir et la construction de l'État en Europe, (Paris, PUF), 416 p. ; Rosanvallon, P. 1992 [1990] L'État en France de 1789 à nos jours (Paris, Le Seuil), 370 p. ; Baruch, M. O. et Duclert, V. (dir.). 2000 Serviteurs de l'État. Une histoire politique de l'administration française, 1875-1945 (Paris, La Découverte), 587 p.

3. Bourdieu, P. 1972 Les stratégies matrimoniales dans le système de reproduction, Annales. Économies, sociétés, civilisations, 4-5, pp.1105-1127; Weber, M. 1995 Économie et Société (Paris, Pocket), 410 et $424 \mathrm{p}$.

4. Petech, L. 1973 Aristocracy and Government in Tibet, 1728-1959 (Roma, Ismeo), 274 p. ; Goldstein, M.C. 1968 An Anthropological Study of the Tibetan Political System (PhD dissertation in Anthropology, University of Washington), 259 p. ; Prince Peter of Greece and Denmark. 1954 The Aristocracy of Central Tibet. A Provisional List of Names of the Noble Houses of Ü-Tsang (Kalimpong, Tibet Mirror Press), 43 p.; Yangdzom, T. 2006 [Chinese version 2005] The Aristocratic Families in Tibetan history, 1900-1951 (Beijing, China Intercontinental Press), $272 \mathrm{p}$.

5. Descimon, R., Schaub, J.-F. et Vincent, B. (dir.). 1997 Les figures de l'administrateur. Institutions, réseaux, pouvoirs en Espagne, en France et au Portugal, 16 $6^{e}-19^{e}$ siècles (Paris, EHESS editions), 242 p.; Reinhard, W. and Descimon, R. (dir.). 1996 Les élites du pouvoir et la construction de l'État en Europe, (Paris, PUF), 416 p. ; Rosanvallon, P. 1992 [1990] L'État en France de 1789 à nos jours (Paris, Le Seuil), 370 p. ; Baruch, M. O. and Duclert, V. (dir.). 2000 Serviteurs de l'État. Une histoire politique de l'administration française, 1875-1945 (Paris, La Découverte), $587 \mathrm{p}$.

6. Bourdieu, P. 1972 Les stratégies matrimoniales dans le système de reproduction, Annales. Économies, sociétés, civilisations, 4-5, pp.1105-1127; Weber, M. 1995 Économie et société (Paris, Pocket), 410 and $424 \mathrm{p}$. 